\title{
Pengembangan LKM Model PBLberbasis Potensi Lokal pada Mata Kuliah Bioteknologi untuk Meningkatkan Kemampuan Berpikir Kritis Mahasiswa Di Universitas Muhammadiyah Kupang
}

\section{Development the Student's Worksheet with Problem-Based Learning (PBL) Model-Based on Local Potential in the Biotechnology Learning Results to Enhance Students' Critical Thinking Skills and Students' Learning Outcomes at the University of Muhammadiyah Kupang}

\author{
NURDIYAH LESTARI ${ }^{{ }^{*}}$, SUCIATI ${ }^{2}$, SUGIYARTO $^{3}$ \\ ${ }^{1}$ Pendidikan Biologi Universitas Muhammadiyah Kupang, \\ ${ }^{2}$ Pendidikan Biologi FKIP Universitas Sebelas Maret \\ ${ }^{3}$ Jurusan Biologi FMIPA Universitas Sebelas Maret \\ *email: : nurdiyah.72@gmail.com
}

Manuscript received: 6 April 2014 Revision accepted: 14 Juli 2014

\begin{abstract}
The purposes of this research were: 1) development of students worksheet Problem Based Learning (PBL) based on Local Potential; 2) test feasibility of the PBL model; 3) determine the effectiveness of PBL model. Analysis of the data used for research and development are qualitative and quantitative descriptive analysis, as well as the percentage techniques. Research and development of PBL models based on local potential uses 4-D model. The results of research and development showed: 1) product of PBL-based models are developed based on the stages of the Local Potential PBL syntax that uses indicators of critical thinking skills, 2) feasibility of the model PBL-based Local Potential according to experts is very well qualified with average of $92,1 \%$, qualified by education practition is very well with average of 94,5 $\%$, whereas according to qualified students an excellent with average of $88,2 \%$; 3) student's worksheet PBL-based Local Potential effectively improve critical thinking skills and learning results with gain value 9 and $\mathrm{N}$-gain value 0.28 at low category. Based on result of $\mathrm{t}$ scores obtainable gain value 9.06 and $\mathrm{N}$-gain value 0.420 at medium category.
\end{abstract}

Keywords: Research and development, PBL model, local potential, biotechnology, critical thinking skills, learning outcomes

\section{LATAR BELAKANG}

Mahasiswa seringkali kesulitan dalam mencari literatur perkuliahan khususnya untuk mata kuliah Bioteknologi. Sumber belajar yang digunakan masih terbatas pada print out dari materi kuliah (Power Point) yang dibuat oleh dosen serta hanya sebagian kecil yang aktif mencari sumber belajar melalui internet. Mahasiswa kurang memiliki kemampuan memecahkan masalah, yang terindikasi dari kurang aktifnya mahasiswa dalam berdiskusi sehingga diskusi tidak berjalan efektif. Selain itu dalam menyelesaikan tugas-tugas yang diberikan oleh dosen, mahasiswa belum memiliki rasa tanggung jawab, serta belum dapat mengerjakan tugas-tugas secara mandiri. Perkuliahan Bioteknologi masih bersifat teoritis dan bersifat ceramah serta kurang memaksimalkan kemampuan mahasiswa dalam melakukan pemikiran secara kritis. Perkuliahan Bioteknologi yang sudah dilaksanakan menggunakan instrumenberupa LKM, namun LKM yang digunakan selama ini kurang memberdayakan kemampuan berpikir kritis mahasiswa karena hanya melakukan kegiatan sesuai petunjuk tanpa memberikan kesempatan pada mahasiswa untuk menemukan konsep sendiri dalam perkuliahan.

Melalui perkuliahan Bioteknologi diharapkan mahasiswa mampu berpikir kritis menemukan solusi terhadap permasalahan dalam kehidupan nyata. LKM yang mampu mendorong mahasiswa berpikir kritis melalui pemecahan masalah dalam kehidupan nyata sangat perlu dikembangkan guna menyelesaikan permasalahan tersebut.

Model PBL (Problem Based Learning) merupakan suatu pola atau suatu rencana yang digunakan sebagai pedoman dalam merencanakan pembelajaran dengan memunculkan suatu permasalahanautentik dari lingkungan sekitar secara nyata yang harus diselesaikan. Sintaks dari model Problem Based Learning adalah diawali darimengorientasikan masalah, mengorganisir untuk meneliti, membantu investigasi, mempresentasikan hasil karya serta menganalisis dan mengevaluasi proses mengatasi masalah. Menurut Hamruni (2012), PBL memberikan kesempatan pada mahasis-wa untuk bereksplorasi, mengumpulkan dan menganalisis data secara lengkap untuk memecahkan masalah yang 
dihadapi. Tujuan yang ingin dicapai adalah kemampuan berpikir kritis, analitis, sistematis, dan logis untuk menemukan alternatif pemecahan masa-lah melalui eksplorasi dan secara empiris dalam rangka menumbuhkan sikap ilmiah. Melalui pembelajaran model PBL diharapkan peserta didik dapat belajar untuk berpikir dan menyelesaikan masalahnya sendiri, karena peran pendidik hanya berfungsi sebagai pembimbing dan fasilitator.

Sumber belajar dapat dirumuskan sebagai segala sesuatu yang dapat memberikan kemudahan kepada peserta didik dalam memperoleh sejumlah informasi, pengetahuan, pengalaman, dan ketrampilan dalam proses belajar mengajar (Mulyasa 2002). Dalam penelitian ini, mata kuliah Bioteknologi diberikan dengan memasukkan potensi lokal berupa tanaman lontar sebagai sumber belajar dalam pembuatan LKM.

Sumber daya alam hayati yang ada di NTT adalah tanaman lontar. Berdasarkan fakta di lapangan, masih banyak potensi tanaman lontar yang belum dimanfaatkan oleh penduduk secara optimal, sehingga dapat dijadikan sebagai sumber belajar dalam proses pembelajaran Bioteknologi. Materi yang diberikan kepada mahasiswa sesuai analisis potensi lontar yang ada berupa materi secara aplikasi atau terapan. Diperlukan suatu teknologi yang tepat dalam memanfaatkan tanaman lontar sehingga diperoleh hasil yang berguna bagi kesejahteraan masyarakat NTT pada umumnya. Teknologi tepat guna tentang pemanfaatan tanaman lontar dituangkan dalam bentuk LKM model PBL.

Sehubungan dengan latar belakang masalah tersebut perlu dikem-bangkan suatu produk instrumen berupa Lembar Kerja Mahasiswa (LKM) dengan model Problem Based Learning berbasis potensi lokal pada mata kuliah Bioteknologi untuk mahasiswa semester VI yang dapat meningkatkan kemampuan berpikir kritis mahasiswa Biologi di Universitas Muhammadiyah Kupang.

Pembelajaran berbasis masalah menurut Dewwey dalam Sudjana (2001) adalah interaksi antara stimulus dengan respons, merupakan hubungan antara dua arah belajar dan lingkungan. Lingkungan memberi masukan kepada siswa berupa bantuan dan masalah, sedangkan system saraf otak berfungsi menafsirkan bantuan itu secara efektif sehingga yang dihadapi dapat diselidiki, dinilai, dianalisis, serta dicari pemecahannya dengan baik.

Menurut Arends (2008), PBL membantu siswa untuk mengembangkan kemampuan berpikir dan ketrampilan mengatasi masalah, mempelajari peran-peran orang dewasa dan menjadi pelajar yang mandiri.Dari perumusan tersebut ternyata bahwa dalam mempelajari sesuatu bahan pelajaran selalu dituntut aktivitas yang berfungsi memecahkan persoalan yang dihadapi. Hal ini berkaitan dengan karakter pembelajaran berbasis masalah, yaitu siswa dituntut untuk belajar secara mandiri dan selalu dikaitkan dengan dunia nyata.

Beberapa hal penting dalam pembelajaran berbasis masalah menurut Arends (2008) adalah:
1. Siswa membuat suatu laporan tertulis yang disebut artefak.

2. Siswa mengatasi masalah - masalah secara "kooperatif " atau bekerja sama dalam kelompok - kelompok kecil.

3. Menggunakan assesmen performance untuk mengatasi masalah -masalah maupun mengukur kerja kelompok.

4. Guru harus dapat menggunakan tehnik pengukuran yang valid dan reliabel.

5. Siswa mempresentasikan hasil / solusi dari masalah yang diinvestigasi.

6. Guru menyodorkan situasi yang bermasalah dan siswa menyelidiki dan menemukan sendiri solusinya.

7. Lingkungan belajar siswa ditandai dengan keterbukaan, keterlibatan aktif siswa, atmosfir kebebasan intelektual.

Ketrampilan berpikir kritis siswa berpengaruh terhadap kualitas pemahaman konsep. Salah satu indikator kemampuan intelektual siswa adalah kemampuan untuk memahami konsep (Sudjana 2006). Cara-cara yang digunakan untuk membangun pemikiran kritis dalam rencana pelajaran adalah:

1. Menanyakan tidak hanya apa yang terjadi, tetapi juga "bagaimana" dan "mengapa".

2. Memeriksa fakta-fakta yang dianggap benar untuk menentukan apakah terbukti untuk mendukung ide-ide baru.

3. Berargumen dengan cara bernalar daripada menggunakan emosi.

4. Mengenali bahwa kadang-kadang terdapat lebih dari satu jawaban atau penjelasan yang bagus.

5. Membandingkan beragam jawaban dari sebuah pertanyaan dan menilai mana yang benar-benar merupakan jawaban yang terbaik.

6. Mengevaluasi dan lebih baik menanyakan apa yang dikatakan orang lain daripada segera menerimanya sebagai kebenaran

7. Mengajukan pertanyaan dan melakukan spekulasi lebih jauh yang telah diketahui untuk menciptakan ideide baru dan informasi baru

Salah satu cara untuk mendorong siswa agar berpikir secara kritis adalah memberikan mereka topik atau artikel kontroversial yang menghadirkan dua sisi permasalahan untuk didiskusikan. Pemikiran kritis ditingkatkan ketika siswa menemui argumen dan perdebatan yang berada dalam konflik, yang dapat memotivasi mereka untuk memecahkan sebuah masalah.

LKM yang telah disusun dibagi dalam beberapa kegiatan belajar sesuai sintaks yang ada dalam pembelajaran berbasis PBL. LKM dilengkapi dengan wacana berupa isu-isu yang sesuai dengan potensi lokal yang ada sesuai karakter dari PBL. LKM berbentuk media cetak, dan terdiri dari judul, identitas, wacanayang sesuai dengan kondisi potensi lokal, kompetensi dasar, serta kegiatan-kegiatan dan soal latihan yang harus diselesaikan mahasiswa. Adapun karakteristik dari LKM yang disusun adalah (1) LKM disusun secara sistematis, (2) Mencantumkan dan menjelaskan tujuan pembelajaran sehingga dapat memandu mahasiswa dalam melakukan 
aktivitas, (3) LKM disusun dengan penciptaan tugas di dalamnya sehingga mahasiswa dapat berlatih mengerjakan soal secara mandiri atau kelompok.

Pengembangan LKM Biotek-nologi menggunakan model PBL berbasis potensi lokal dalam penelitian ini menggunakan model prosedural yang mengadopsi model 4D dari Thiagarajan, Semmel dan Sammel (1974). Model pengembangan 4D terdiri dari define (pendefinisian), design (perancangan), develop (pengembangan), dan desseminate (penyebaran) (Trianto, 2010).

Pengembangan LKM dilakukan dengan memilih sumber belajar yang berupa potensi lokal berupa tanaman lontar yang ada di lingkungan kampus dan disajikan dalam bentuk wacana dengan mengangkat permasalahanpermasalahan autentik yang harus diselesaikan dalam proses pembelajaran.

\section{METODE}

Penelitian dilaksanakan di Universitas Muhammadiyah Kupang dengan uji coba pada mahasiswa semester VI dan tahap disseminate berupa data respon dosen terhadap LKM Bioteknologi dilakukan di Universitas PGRI Kupang. Penelitiandimulai pada bulan Mei 2013 hingga bulan Juni 2014. Instrumen yang digunakan untuk mengumpulkan data dalam penelitian adalah:

1. Lembar validasi LKM dari pakar, dosen dan mahasiswa.

2. Soal tes kemampuan berpikir kritis dan hasil belajar.

Prosedur pengembangan LKM Bioteknologi model PBL berbasis potensi lokal yang dilakukan adalah sebagai berikut :

\section{Tahap Pendefinisian (Define)}

Tahapan pendefinisian merupakan tahap awal dalam prosedur pengembangan yang mencakup semua kegiatan pengambilan data untuk analisis kebutuhan.

\section{Tahap Perancangan (Design)}

Tahapan perancangan dilakukan dengan merancang LKM Bioteknologi model PBL berbasis potensi lokal. Perancangan LKM tersebut didasarkan pada permasalahan yang telah dianalisis pada tahap define (pendefinisian), sehingga LKM yang dikembangkan adalah merupakan LKM yang didesain untuk mengatasi semua permasalahan yang ada.

\section{Tahap Pengembangan (Develop)}

Pengembangan LKM model PBL berbasis potensi lokal pada tahap develop dilakukan sesuai hasil perancangan pada tahap design.

\section{Tahap Penyebaran (Disseminate)}

Tahap penyebaran merupakan tahap penyebarluasan produk yang telah layak untuk semua pengguna. Tahap ini merupakan tahap penggunaan perangkat pada skala yang lebih luas. Tujuan dari tahap penyebaran adalah untuk menguji efektivitas penggunaan perangkat di dalam KBM.

Data yang diperoleh berupa data kualitatif dan kuantitatif. Pada penelitian ini, digunakan tehnik analisis deskriptif kualitatif dan kuantitatif. Deskriptif kualitatif berdasarkan skor data dari validasi ahli materi
Bioteknologi, uji perorangan, ahli pengembangan LKM model PBL, dan uji coba lapangan. Teknik persentase digunakan untuk menyajikan data yang berupa frekuensi atas tanggapan subjek uji coba terhadap produk LKM Bioteknologi

Teknik analisis digunakan untuk mengolah data yang diperoleh melalui angket dalam bentuk persentase dari masing-masing subjek dengan rumus:

$$
\mathrm{P}=\sum \mathrm{xi} \frac{\mathrm{x} 100 \%}{\sum \mathrm{x}}
$$

Keterangan :

$\mathrm{P}=$ Persentase penilaian

$\Sigma \mathrm{xi}=$ Jumlah jawaban dari validator

$\Sigma \mathrm{x}=$ Jumlah jawaban tertinggi

Selanjutnya untuk menghitung persentase keseluruhan subjek/komponen digunakan rumus:

$$
\mathrm{P}=\frac{\sum \mathrm{p}}{\mathrm{n}}
$$

Keterangan :

$\Sigma \mathrm{p}=$ jumlah persentase keseluruhan komponen $\mathrm{n}=$ banyak komponen

Analisis deskriptif kuantitatif digunakan untuk menghitung data hasil respon peserta didik terhadap pembelajaran menggunakan LKM model PBL berbasis Potensi Lokal dengan menggunakan rumus :

$$
\mathrm{SR}=\frac{\text { Total }- \text { skor } \times 100}{\mathrm{~N}}
$$

Keterangan :

$\mathrm{SR}=$ Skor rata

$\mathrm{n}=$ Jumlah sampel

Hasil skor rata-rata disesuaikan dengan tingkat pencapaian sehingga dapat ditentukan kualifikasi LKM yang akan diterapkan.

\begin{tabular}{ccc}
\hline $\begin{array}{c}\text { Tingkat } \\
\text { pencapaian }\end{array}$ & Kualifikasi & Keterangan \\
\hline $90 \%-100 \%$ & Sangat baik & Tidak perlu direvisi \\
$75 \%-89 \%$ & Baik & Tidak perlu direvisi \\
$65 \%-74 \%$ & Cukup & Direvisi \\
$55 \%-64 \%$ & Kurang baik & Direvisi \\
$0 \%-54 \%$ & Kurang cukup & Direvisi \\
\hline
\end{tabular}

Mulyadi (2011)

Selain analisis deskriptif, penelitian ini juga menggunakan analisis kuantitatif sebagai wujud dari uji efektifitas LKM Bioteknologi model PBL berbasis potensi lokal dalam memberdayakan kemampuan berpikir kritis mahasiswa. Teknik analisis statistik yang digunakan 
adalah dengan uji $\mathrm{t}$ ( $\mathrm{t}$ test) menggunakan bantuan program SPSS 16 yang didahului uji prasyaratnya yaitu uji homogenitas dan normalitas. Uji normalitas digunakan untuk mengetahui apakah data berdistribusi normal atau tidak. Uji normalitas terhadap pretest-posttest dilakukan dengan Uji Kolmogorov-Smirnov. Uji homogenitas dilakukan untuk mengetahui data berasal dari variansi yang sama atau tidak.

\section{HASIL DAN PEMBAHASAN}

Produk yang dikembangkan berupa LKM dengan model Problem Based Learning (PBL) berbasis potensi lokal pada mata kuliah Bioteknologi. LKM yang disusun menggunakan satu Kompetensi Dasar (KD) yaitu mendeskripsikan dan memberikan contoh tentang penerapan prinsip-prinsip Bioteknologi dalam ber-bagai bidang: pertanian, peternakan, perikanan dan kesehatan.

LKM yang telah dikembangkan berbeda dengan LKM pada umumnya karena menggunakan modelProblem Based Learning (PBL). Pembelajaran berbasis masalah yang dipilih dalam penyusunan LKMdapat meningkatkan kemampuan berpikir kritis dengan melatih keterampilan memecahkan masalah berupa wacana terkini, petunjuk melakukan eksperimen, serta beberapa pertanyaan yang dapat melatih kemam-puan mahasiswa. Situasi - situasi yang ada dalam PBL antara lain memberikan orientasi tentang permasalahan, pengor-ganisasian untuk meneliti, investigasi, kolaboratif, presentasi artefak atau exhibit, analisis solusi. LKM yang diterapkan dibagi dalam beberapa kegiatan belajar sesuai sintaks yang ada dalam pembelajaran dengan model PBL. LKM dilengkapi dengan wacana berupa isu-isu yang sesuai dengan potensi lokal yang ada sesuai karakter dari PBL.

LKM berbentuk media cetak, dan terdiri dari judul, identitas, wacana yang sesuai dengan kondisi potensi lokal, kompetensi dasar, serta kegiatan-kegiatan dan soal latihan yang harus diselesaikan mahasiswa. Adapun karakteristik dari LKM yang disusun adalah

1. LKM disusun secara sistematis,

2. Mencantumkan dan menjelaskan tujuan pembelajaran sehingga dapat memandu mahasiswa dalam melakukan aktivitas,

3. LKM disusun dengan penciptaan tugas di dalamnya sehingga mahasiswa dapat berlatih mengerjakan soal secara mandiri atau kelompok

Tabel 2. Hasil Validasi Pakar

\begin{tabular}{lcccc}
\hline Produk/draf I & \multicolumn{2}{c}{ Skor } & Jumlah & Kategori \\
\cline { 2 - 3 } & V1 & V2 & & \\
\hline Perangkat & & & & \\
$\begin{array}{l}\text { Pembelajaran } \\
\text { Silabus }\end{array}$ & 38 & 36 & 74 & Baik \\
RPP & $\mathbf{5 5}$ & $\mathbf{5 3}$ & $\mathbf{1 0 8}$ & Sangat baik \\
LKM & $\mathbf{5 8}$ & $\mathbf{6 2}$ & $\mathbf{1 2 0}$ & Sangat baik \\
\hline
\end{tabular}

Tabel 3. Hasil Validasi Dosen Bioteknologi

\begin{tabular}{lcccc}
\hline \multicolumn{1}{c}{ Produk/draf I } & \multicolumn{2}{c}{ Skor } & Jumlah & Kategori \\
\cline { 2 - 3 } & V1 & V2 & & \\
\hline Perangkat & & & & \\
Pembelajaran & 40 & 38 & 78 & Baik \\
Silabus & 60 & 57 & 117 & Sangat baik \\
RPP & 62 & 61 & 123 & Sangat baik \\
LKM &
\end{tabular}

Tabel 4. Respon Mahasiswa terhadap LKM

\begin{tabular}{lcll}
\hline \multicolumn{1}{c}{ Aspek } & $\begin{array}{c}\text { Skor } \\
(\%)\end{array}$ & Kategori \\
\hline Kelayakan LKM secara keseluruhan & 95 & Sangat baik \\
Kelayakan penyajian & 98 & Sangat baik \\
Isi & 96 & Sangat baik \\
Kesesuaian dengan model PBL & 80 & Baik \\
$\begin{array}{l}\text { Kesesuaian dengan kemampuan } \\
\text { berpikir kritis }\end{array}$ & 72 & Baik \\
\hline
\end{tabular}

Hasil skor rata-rata validasi pakar sebesar 90,01\% (sangat baik), dari dosen biologi $84,05 \%$ (baik) dan mahasiswa 76,20\% (baik), sehingga LKM dinyatakan telah memenuhi kualifikasi tanpa revisi. Deskripsi kemampuan berpikir kritis dan deskripsi kemampuan kognitif mahasiswa berdasarkan skor pretest dan posttest setelah mengikuti pembelajaran Bioteknologi menggunakan LKM model PBL disajikan pada Tabel 5.

Tabel 5. Hasil Pretest dan Postest (Berpikir kritis)

\begin{tabular}{cccccc}
\hline $\begin{array}{c}\text { Jenis } \\
\text { Tes }\end{array}$ & Jml & Min & Maks & $\begin{array}{c}\text { Rata- } \\
\text { rata }\end{array}$ & $\begin{array}{c}\text { Std. } \\
\text { Dev }\end{array}$ \\
\hline Pretest & 34 & 40 & 70 & 53,088 & 9,047 \\
Postest & 34 & 50 & 75 & 62,06 & 7,398 \\
\hline
\end{tabular}

Dari hasil pretest dan posttest diperoleh Nilai Gain dan $N$-gain untuk menunjukkan adanya perbedaan/kenaikan dari pretest ke posttest. Tabel 6 menunjukkan deskripsi data gain dan $N$-gainberdasarkan nilai pretest dan posttest sesudah pembelajaran dengan menggunakan LKM model PBL pada materi Bioteknologi.

Tabel 6. Hasil Data Gain dan N-gain

\begin{tabular}{cccccc}
\hline $\begin{array}{c}\text { Jenis } \\
\text { data }\end{array}$ & N & Min & Mak & $\begin{array}{c}\text { Rata- } \\
\text { rata }\end{array}$ & Std.Dev \\
\hline Gain & 34 & 0 & 20 & 9 & 9,047 \\
N-gain & 34 & 0 & 0,65 & 0,28 & 7,398 \\
\hline
\end{tabular}

Berdasarkan Tabel 6 dapat dilihat data gain dan gain ternormalisasi ( $N$-gain) dari 34 mahasiswa, yang dapat digunakan untuk mengetahui peningkatan kemampuan berpikir kritis mahasiswa setelah pembelajaran dengan menggunakan LKM dengan model PBL. 
Berdasarkan uji t diperoleh hasil sebesar 6,410 dengan signifikansi sebesar $0,000 \quad(<0,05)$ maka dapat disimpulkan bahwa terdapat perbedaan skor yang signifikan terhadap hasil tes berpikir kritis pretest dan posttest.Hal ini menunjukkan bahwa LKM Bioteknologi menggunakan model PBL efektif meningkatkan kemampuan berpikir kritis mahasiswa.

Gambar 1 menunjukkan bahwa perolehan terbanyak berada pada rentang kategori sedang yaitu sebanyak 20 mahasiswa. Sedangkan nilai gain rendah menunjukkan adanya peningkatan kemampuan berpikir relative rendah, yang terdapat pada 14 mahasiswa. Namun jika dilihat dari rata - rata nilai gain diperoleh data sebesar 9, dan rata-rata $N$-gain sebesar 0,28 dengan ratarata nilai pretest sebesar 53,00 dan rata-rata nilai posttest sebesar 62,06. Dengan demikian dapat disimpulkan bahwa mahasiswa secara keseluruhan memperoleh peningkatan kemampuan berpikir kritis pada kategori rendah.

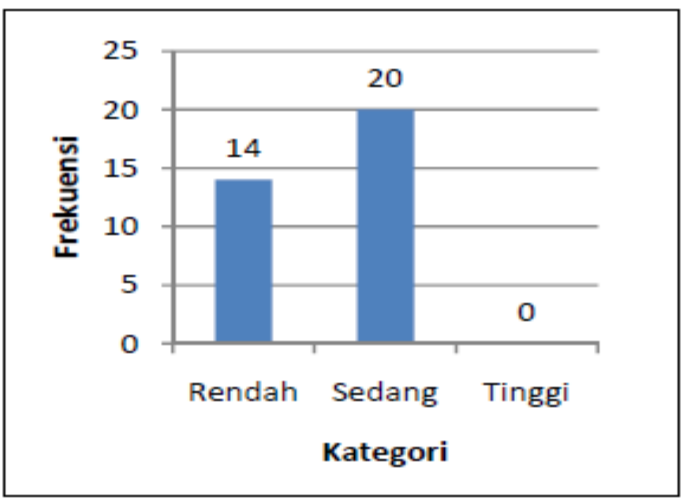

Gambar 1. Distribusi Tingkat Capaian Kemampuan Berpikir Kritis Mahasiswa

Menurut Brookfield (dalam Liliasari 2010), merumuskan esensi berpikir kritis: 1) berpikir kritis adalah aktivitas produktif dan positif, 2) manifestasi berpikir kritis bergantung pada konteks, 3) berpikir kritis merupakan aktivitas emosional dan rasional. Hal senada dikemukakan oleh Zahrah dan Rezaii (2013), yaitu proses pembelajaran yang menekankan pada pengembangan kemampuan berpikir kritis akan meningkatkan prestasi belajar secara signifikan.

\section{KESIMPULAN}

Kelayakan LKM model PBL berbasis potensi lokal pada mata kuliah Bioteknologi berkategori "Baik " setelah dilakukan uji coba lapangan.

LKM efektif meningkatkan kemampuan berpikir kritis mahasiswa, dilihat dari kemampuan mahasiswa memecahkan permasalahan, dapat membangun konsep sendiri dalam proses pembelajaran, serta mampu mempresentasikan hasil karya berupa laporan hasil kegiatan.

Peningkatan kemampuan berpikir kritis dan hasil belajar mahasiswa cukup signifikan tetapi dalam kategori "rendah" setelah diterapkan LKM model PBL berbasis potensi lokal.

\section{REKOMENDASI}

Penggunaan LKM model PBL berbasis lotensi lokal pada materi Bioteknologi dapat diterapkan dengan baik dalam pembelajaran di Universitas Muhammadiyah Kupang.

Penggunaan model PBL berbasis potensi lokal pada materi Bioteknologidapat meningkatkan kemampuan berpikir kritis mahasiswa.

\section{DAFTAR PUSTAKA}

Arends, L.R. 2008. Learning To Teach, Belajar untuk mengajar. Yogyakarta: Pustaka Pelajar

Elina S.M. 2012. Pengembangan Buku Ajar Materi Bioteknologi Di Kelas XII SMA Ipiems Surabaya Berorientasi Sains, Teknologi, Lingkungan, Dan Masyarakat (SETS). BioEdu 2(1) : $15-18$

Fascione, P.A. 2011. Critical Thinking: What It Is and Why I Counts. California : California Academic Press

Fisher A, 2008. Critical Thinking: An Introduction (terjemahan). Jakarta: Erlangga

Hamruni. 2012. Strategi Pembelajaran, Yogyakarta: Insan Madani

Haseli, Z and F. Rezaii. 2013. The Effect of Teaching Critical Thinking on Educational Achivement Among High School Student in Saveh. European Online Journal of Natural and Social Sciences. 2 (2): 245 - 261

Mulyasa, E. 2002. Kurikulum Berbasis Kompetensi. Bandung: Remaja Rosdakarya

Sarwi dan Liliasari. 2010. Penumbuhkembangan Ketrampilan berpikir Kritis Calon Guru Fisika melalui Penerapan Strategi Kooperatif Dan Pemecahan Masalah Pada Konsep Gelombang. Forum Kependidikan.30 (1): 1-94

Sudjana, 2006. Penilaian Hasil Proses Belajar Mengajar. Bandung: PT Remaja Rosdakarya.

Thiagarajan. 1974. Instructional Development for Training Teachers of Exceptional Children A Sourcebook. Indian: Indiana University. 